\title{
JOURNAL.RU
}

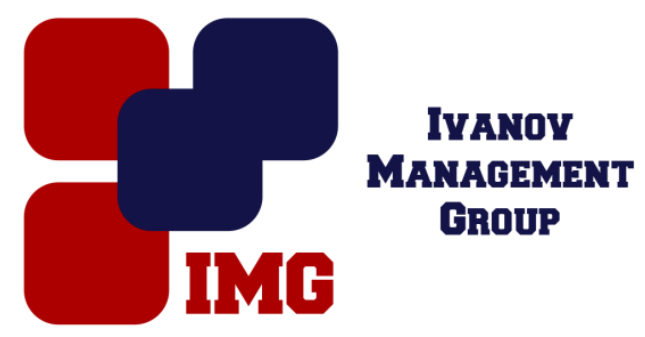

Антонов М.В. Санкт-Петербургский государственный экономический университет", институт магистратуры Санкт-Петербург, Россия

doi: $10.18411 / 1 \mathrm{j}-31-05-2017-56$

idsp 000001:1j-31-05-2017-56

\section{Использование менеджмента для развития государственно-частного партнёрства в индустрии спорта РФ}

\section{Аннотация}

В настоящее время развитие физической культуры и спорта является одним из приоритетных направлений России. Это подтверждается количеством международных спортивных мероприятий, в которых Россия в ближайшее время примет участие и которые планирует принять на своей территории. В связи с этим для массового и профессионального спорта необходимы значительные инвестиции, как государственного, так и частного секторов экономики. И тем самым, необходимы специалисты, менеджеры - руководители рыночного типа, работа которых направлена на объект - хозяйственную деятельность организации.

Ключевые слова: менеджмент, спорт, физическая культура, ГЧП, финансирование.

Менеджмент как профессиональный вид деятельности по управлению людьми в отраслях экономики, где предполагается получение прибыли как конечного результата, подразумевает наличие субъектов управления менеджеров. Менеджеры в нашем понимании - руководители рыночного типа, работа которых направлена на объект - хозяйственную деятельность организации. Они возглавляют коммерческие организации, выполняя управленческие функции и принимая стратегические решения.[1] 
В настоящее время развитие физической культуры и спорта является одним из приоритетных направлений России. Это подтверждается количеством международных спортивных мероприятий, в которых Россия в ближайшее время примет участие и которые планирует принять на своей территории. В связи с этим для массового и профессионального спорта необходимы значительные инвестиции, как государственного, так и частного секторов экономики.

На сегодняшний день для поддержки отрасли спорта только бюджетных финансовых средств недостаточно. Ежегодные расходы бюджетов всех уровней составляют около $0,7 \%$ к общей сумме расходов и согласно данным федерального бюджета РФ на 2013-2015 гг. предполагается уменьшение доли финансирования физической культуры и спорта на $0,6 \%$ к ВВП. В свою очередь Стратегия развития физической культуры и спорта до 2020 г. предполагает увеличение количества людей, занимающихся спортом с 15\% до 40\%, количество стадионов, спортивных комплексов и спортивных площадок. В этих условиях осуществляется активный поиск дополнительных средств для строительства объектов спортивных объектов, повышения эффективности использования бюджетных средств на эти цели и обеспечения эффективного сочетания интересов бизнеса и государства. В качестве такого инструмента на первый план выдвигается государственно-частное партнерство (ГЧП).

Но, ГЧП не будет успешным, если в этом не принимают участие профессиональные менеджеры. Сейчас остро стоит вопрос о наличии грамотных специалистов, которые владеют основами маркетинга, фандрайзинга, PRтехнологиями и инновационными методами.

Для этого, необходимо учитывать положительный опыт зарубежных партнёров.

Например, в Европе механизм ГЧП в спортивной отрасли применяет уже свыше 20 лет. На западе отношения государства и бизнеса не ограничиваются организацией спортивных мероприятий, созданием или реконструкцией спортивных объектов с применением частного капитала. Например, в Великобритании, Австралии и Испании на основе ГЧП реализуются проекты по подготовке специалистов в области спорта, в том числе профессиональных спортсменов. При этом в партнерстве участвуют не только представители государства и бизнеса, но и высшие учебные заведения, социальноориентированные общественные организации. 
Строительство Сингапурского спортивного комплекса проводилось на базе Сингапурского Национального Стадиона. По проекту на месте стадиона должен быть возведен многофункциональный спортивный и развлекательный комплекс, включающий: новый национальный стадион вместимостью 55 тыс. мест; спортивный манеж; многофункциональную крытую арену; многофункциональный акваманеж; смешанные зоны (развлекательные центры, конференц-залы, ресторанная и торговая зона, фитнес-центры, центр спортивной информации и исследований, центр спортивной медицины и науки, коммерческую недвижимость - 41 тыс. кв. м); парковочный комплекс. Реализация проекта осуществлялась исходя из следующих особенностей [2]:

1) форма ГЧП: контракт жизненного цикла (концессия), заключенный сторонами на 25 лет и предусматривающий, что концессионер разрабатывает проект, осуществляет строительство, обеспечивает финансирование и осуществляет управление комплексом (DBFO). Концедент производит ежегодный однократный платеж (unitarypayment), выплата которого начинается со стадии эксплуатации, и регулярные платежи, связанные с объемом согласованных услуг/параметров коэффициента использования (availabilityparameters). Проект также генерирует прибыль от проведения различных мероприятий, поступающих в распоряжение концессионера.

2) КЖЦ предусматривает: возможность распределения сверхприбыли (sharingofrevenueupside); возможность привлечения субподрядчиков к выполнению отдельных видов работ; механизм замены сервисной компании; "дни мероприятий стадиона" и прибыль третьих лиц; соотнесение платежей по обязательствам с индексом цен (индексация).

3) Обязательным условием Совета Сингапура по спорту при реализации проекта концессионером было обеспечение интеграции спортивного комплекса в городское пространство;

4) Риски распределяются между сторонами по установленным стандартам формы DBFO (КЖЦ);

5) В качестве основного инвестора выступает компания HSBC InfrastructureFund, генерального подрядчика - компания Dragages, оператора объекта - компания UnitedPremas, оператора стадиона - компания GlobalSpectrum.

6) Финансирование проекта осуществлялось посредством проектного финансирования с ограниченным правом регресса на заемщика. Инвесторами специально созданной проектной компании (SPV) выступил консорциум 11 
национальных и иностранных банков, предоставивший кредит на срок в десять лет, на общую сумму в 1.8 млрд. долларов.

Обозначенный выше пример успешной реализации крупного ГЧП-проекта в спортивной сфере показывает заинтересованность инвесторов в их финансировании при наличии проработанной законодательной базы и государственных гарантиях. В связи с чем, имеет особую важность принятие Федерального Закона о ГЧП, который позволит вывести применение ГЧП в спортивной сфере (да и других тоже) на новый этап развития. Отметим, что отечественный законодатель очень инициативен в этой сфере, понимает «нужды» инвесторов и их озабоченность рисками участия в капиталоемких проектах. Как следствие, был внесены изменения в законодательство о секьюритизации активов (возможность применения российского права к финансированию сделок посредством специализированных обществ), получило серьезное развитие ГЧП в сферах автодорожного строительства, ЖКХ и ТЭК через существенное обновление концессионного законодательства, продолжается структурная реформа действующего гражданского законодательства и т.д., что позволяет ожидать дальнейшего развития института ГЧП в сфере спорта в России.

В России, также есть успешные проекты по привлечению коммерческих партнёров в индустрию спорта. И при этом большую часть проектов проводили высококвалифицированные менеджеры и маркетологи, у которых была чёткая стратегия на будущее привлечение финансовых средств.

Наиболее богатый опыт привлечения частных денег в создание спортивной инфраструктуры разработан в Нижегородской области. Три физкультурно-оздоровительных комплекса (ФОК) в Павловском, Лукояновском и Краснобаковском районах построены в рамках концессионных соглашений между Нижегородской областью и ЗАО «Волга - Спорт». Концессионные соглашения были заключены в октябре 2010 г. на 10 лет, в рамках которых частный партнер обязуется профинансировать, построить, оснастить оборудованием данные спортивные сооружения. Стоимость каждого ФОКа составила порядка 500 млн. рублей. По истечении десятилетнего периода объекты будут переданы области, а до этого момента хозяйственную деятельность на них будет осуществлять частный партнёр.

В Калининграде построен спортивный комплекс, включающий универсальный спортзал, бассейн и ледовую арену. Реализация проекта обошлась в 363 млн. рублей, из которых 51\% составляют бюджетные 
инвестиции, а 49\% - частные. При реализации данного проекта также был применён механизм концессионного соглашения.

В Бурятии, в пос. Саган-Нур построен бассейн. Этот проект реализован по схеме контракта жизненного цикла. Стоимость строительства составила 54 млн. рублей, - область и частный партнёр ОАО «СУЭК» поделили финансовое участие в равных долях.

В Ульяновской области реализован проект по строительству ледового дворца. Так, Ульяновский объект построен на месте старого спорткомплекса «Торпедо». Общая стоимость работ по проекту составила порядка 1,3 млрд. рублей. В 2012 г. было подписано концессионное соглашение между областью и ЗАО «Волга-спорт», по условиям которого все строительные работы завершили к концу 2013 г. Соглашение действует в течении десяти лет с момента сдачи спорткомплекса в эксплуатацию. Экономический эффект рассчитывался опытными менеджерами и разбивался на три составляющие: прямой, косвенный и индуцированный эффект. В случае ЧМ в Ульяновске общий экономический эффект, по оценке РwC, составил 290 млн рублей, из которых 122 млн - прямой эффект, 168 млн - косвенный. При этом не брался в расчет эффект от реконструкции стадионов, освещения события в СМИ, популяризация Ульяновска как места проведения соревнований, развитие кадрового состава, продвижение волонтерства и физической культуры.

Ледовый дворец в Чебоксарах стал самым крупным современным спортивным сооружением в Чувашии, на строительство которого потратили более 1,2 млрд. рублей (из которых 600 млн. рублей (50\%) составляют частные инвестиции ОАО «Газпром»).

В Архангельской области построили лыжно-биатлонный комплекс «Онега», стоимостью 490 млн. рублей. Основная цель реализации проекта была - повышение привлекательность области для туристов и энтузиастов данных видов спорта. Власти области и частный инвестор планировали, что первые посетители комплекса смогут воспользоваться его сервисами уже в 2013 г.

Фактически, первым международным спортивным мероприятием в России, подготовка ряда объектов к которому происходит по модели ГЧП, является Чемпионат мира по футболу 2018 года. В частности, государство рассчитывает на поддержку отдельных предпринимателей в строительстве стадионов «Зенит-Арена» (при поддержке ОАО «Газпром»), а также ряд иных стадионов и объектов инфраструктуры в субъектах РФ, которые будут принимать участие в проведении футбольных соревнований (например, в 
Мордовии будет осуществлена застройка территории вокруг стадиона). Вместе с тем, нельзя не отметить рост популярности ГЧП в строительстве спортивных объектов (физкультурно-спортивные комплексы, бассейны, ледовые дворцы и др.).

Стоит отметить, что, исходя из российского и зарубежного опыта реализации ГЧП проектов, в этом сегменте существуют некоторые проблемы:

1. неопределенность в сфере государственных форм собственности (заинтересованный в заключении соглашения потенциальный партнер не уверен в наличии у органов власти надлежащих полномочий, необходимых для реализации всех положений заключаемого соглашения), зачастую недоверие частного бизнеса к модному инструменту ГЧП, а также неспособность покрыть банковские риски (до $30 \%$ от итоговой стоимости капитальных вложений) инициатором проекта ГЧП, структурированного на условиях проектного финансирования;

2. правила бюджетного учета и установления тарифов, не предоставляют необходимые гарантии потенциальному частному инвестору по определению уровня будущих денежных потоков для окупаемости проектов (установленная Федеральной службой по тарифам система тарифов создает дополнительные трудности для участников сделок ввиду ее фактического дублирования при расчетах, проводимых потребителями за все коммунальные услуги);

3. стоимость строительства 1 кв. м. объекта спортивной инфраструктуры существенно отличается в зависимости от региона его реализации, что говорит об отсутствии единых стандартов строительства в стране и существенных региональных отличиях;

4. не проработан вопрос залогового законодательства, что создает проблемы для банков по финансированию ГЧП на основе проектного финансирования и требует обращения к западному законодательству (чаще английскому праву) для структурирования сделок (сложившуюся в настоящее время ситуацию большинство инвесторов характеризуют как запутанную, поскольку зачастую вопрос по взысканию заложенного имущества в случае дефолта в судебном порядке затягивается или его невозможно разрешить по причине отсутствия неоспоримых и четких формулировок в законодательных и иных актах).

В тоже время за счет развития ГЧП в спортивной отрасли национальная экономика получает несколько полезных эффектов, таких как: снижение 
государственного финансирования разнообразных физкультурно-спортивных программ федерального и местного уровня; развитие социально значимой сферы предпринимательской деятельности, за счет которой население становится более здоровым, создаются новые рабочие места; увеличение налоговых поступлений в бюджеты всех уровней за счет развития спортивной отрасли. Формирование государственно-частных институтов в России возможно на основе создания определенной институциональной среды. [3] Основной проблемой остается нехватка бюджетного финансирования строительства новых спортивных стадионов, площадок, физкультурно-оздоровительных комплексов, а также реконструкция и модернизация существующих. В такой ситуации государству необходимо дать органам местного самоуправления четкие полномочия и предоставить возможность действовать самостоятельно при решении вопросов, связанных с заключением соглашений о ГЧП, предоставить соглашениям о ГЧП реальную юридическую силу, прояснить ситуацию с правами собственности на объекты соглашений о ГЧП. Несмотря на указанные выше проблемы и несовершенство законодательства, данный альянс позволяет решить поставленные задачи перед государством в социальной сфере по выполнению общественно-значимых услуг, а для частного сектора находить новые сферы вложения инвестиций, а также создавать новые рабочие места.

\section{Выводы}

Обзор только реализуемых проектов в спортивной инфраструктуре, а также перспективы новых свидетельствуют, что в России есть значительные перспективы для применения механизмов ГЧП в спорте. Но для ускорения данного процесса необходимо совершенствование нормативно-правовой базы, и с этой целью в настоящее время рассматривается в Государственной Думе РФ Федеральный Закон о ГЧП, разработанный Минэкономразвития и экспертным сообществом с участием ведущих институтов развития ГЧП на основе региональных законов. Несомненную пользу принесёт расширение применения новых схем государственно-частного партнерства. Стоит ожидать значительного роста количества спортивных объектов, построенных с использованием механизмов ГЧП в свете предстоящих чемпионатов мира по хоккею и футболу, которые пройдут в России в 2016 и 2018 гг. в России.

Таким образом, потребность в опытных менеджерах и использование менеджмента для развития государственно-частного партнёрства в индустрии спорта РФ будет максимально востребовано на протяжении многих лет. 
1. Каргина Р. Ю. Проблемы и перспективы развития российского менеджмента [Текст] // Инновационная экономика: материалы Междунар. науч. конф. (г. Казань, октябрь 2014 г.). - Казань: Бук, 2014. - С. 153-155.

2. Более подробно об этом и ряде других успешных зарубежных ГЧП-проектах см.: Долгов А., Макаревич, К. Государственно-частное партнерство в сфере строительства объектов спортивной инфраструктуры: международный опыт и перспективы в России // Корпоративный юрист. - 2011.- №3.- С. 9-13.

3. Петрикова Е. М., Слободянюк Н. В. «Государственно-частное партнёрство спортивной индустрии России»http://www.rea.ru/ru/org/managements/izdcentr/Pages/vestnikeld.aspx, ФГБОУ ВО «РЭУ им. Г.В. Плеханова». 